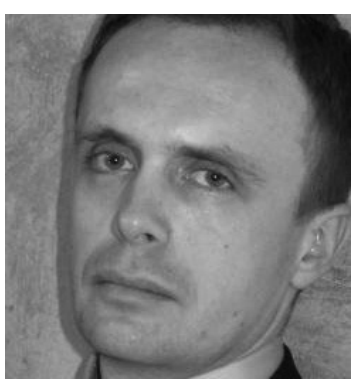

Marek Kochanowski

Marek Kochanowski - doktor, adiunkt w Zakładzie Literatury Pozytywizmu i Młodej Polski Uniwersytetu w Białymstoku, animator i popularyzator kultury, zajmuje się literaturą Młodej Polski, estetyką modernistyczną, literaturą popularną, twórczością Witkacego. Opublikował liczne artykuły poświęcone m.in. prozie Reymonta, Witkacego, Struga, Grabińskiego. Autor książki Powieści Witkacego wobec schematów literatury popularnej (2007), redaktor tomów: Twórczość Wiesława Kazaneckiego (2010) oraz (wraz z J. Zacharską) Wiek kobiet w literaturze (2002). Wybrane artykuły: Dobre wychowanie. Listy Stanisława Witkiewicza do syna; Uwagi o kompozycji „Demona ruchu" S. Grabińskiego; Parodia mitu żółtego niebezpieczeństwa w "Nienasyceniu" Stanisława Ignacego Witkiewicza. 


\section{Dialektyka ruchu i pożądania w opowiadaniu $W$ przedziale Stefana Grabińskiego}

powiadanie $W$ przedziale jest trzecim w kolejności utworem w tomie Stefana Grabińskiego pt. Demon ruchu, który został po raz pierwszy wydany w 1919 roku. W trzy lata później ukazuje się poszerzona wersja zbioru, do którego wstęp napisał Józef Jedlicz ${ }^{1}$. Tematyka całości związana jest $\mathrm{z}$ demonicznymi i nadprzyrodzonymi wydarzeniami rozgrywającymi się w świecie szeroko rozumianego kolejnictwa. Równie istotne w całym tomie jest szaleństwo; występuje ono w każdym tekście zbioru. W opowiadaniu $W$ przedziale, jako jedynym tekście w cyklu, brak jest akcentów metafizycznych czy fantastycznych, nie ma też wskazywanych przez badaczy, charakterystycznych dla Grabińskiego spirytyzmu i mistycyzmu². Fabuła jest prezentowana poprzez opis relacji w trójkącie erotycznym z bardzo silnym motywem zazdrości i zbrodni włącznie ${ }^{3}$. To prawdopodobnie mało skomplikowana tematycznie - jak na pozostałe teksty Grabińskiego - fabuła utworu sprawiła, że krytycy nie poświęcili mu specjalnej uwagi. W największej jak do tej pory monografii spuścizny pisarza, autorstwa Artura Hutnikiewicza, omówienie opowiadania $W$ przedziale zajmuje zaledwie kilka zdań. Zagadnieniem podstawowym dla niniejszych rozważań są wobec tego pytania o celowość i sensowność umieszczenia tytułowej noweli w zbiorze składającym się z „opowieści niesamowitych” oraz o rolę pociągu, jego związku z ruchem i z pożądaniem.

Kompozycja Demona ruchu jest niezwykle kunsztowna i przemyślana, miejsce omawianego utworu w układzie całego cyklu nie wydaje się przypadkowe, jego fabuła zawiera wiele czynników dynamizujących tom; to bodajże najbardziej skondensowany czasowo i tematycznie tekst Demona ruchu, w swoim nastroju i konstrukcji znacznie różniący się od

\footnotetext{
1 Większość wydań powojennych pomija opowiadania W przedziale i Wieczny pasażer, prawdopodobnie ze względu na brak w nich pierwiastków niesamowitych. Mam tu na myśli edycję z roku 1975 (NO) i 1980 (N). W tekście korzystam z jedynego po II wojnie światowej pełnego wydania Demona ruchu (1999). Omawiane opowiadanie zaznaczam w tekście skrótem WP z numerem strony w nawiasie.

2 Zob. TLSG; M. Adamiec, Cień wielkiej tajemnicy. Rzecz o opowieściach Stefana Grabińskiego, „Twórczość” 1982, nr 7; M. Kochanowski, Uwagi o kompozycji „Demona ruchu” Stefana Grabińskiego, [w:] Cykl literacki w Polsce , red. K. Jakowska, B. Olech, K. Sokołowska, Białystok 2001.

3 Zbrodnia w pociągu doczekała się swojego oddzielnego omówienia: I. Carter, Crime On the Line, Crime On the Train, [w:] idem, Railways and Culture in Britan: The Epitome of Modernity, Manchester 2001.
} 
pozostałych części. Dwa poprzedzające go opowiadania, w ostatniej redakcji zbioru z 1922 roku, zawierają elementy prozy poetyckiej, poetyki marzenia sennego i halucynacji. Fabuła pierwszego tekstu, czyli Gluchej przestrzeni, ma charakter statyczny, wprowadzający w tematykę Demona ruchu, do końca nie wiemy, na ile Szymon Wawera, główny bohater tego opowiadania, rzeczywiście widzi wjeżdżający pociąg i swoich zmarlych kolegów; być może jego wizje są wynikiem stanu psychicznego bohatera. Drugi w kolejności utwór, zatytułowany Smoluch, to historia starszego konduktora Błażeja Boronia, który spotyka demona zwanego Smoluchem, zapowiadającego kolejowe katastrofy. Finał tego tekstu opisywany jest z pozycji zewnętrznej wobec prezentowanej historii, czytelnik obserwuje wypadek wywołany przez samego Boronia, który w ten sposób pragnie udowodnić, iż każde pojawienie się Smolucha prowadzi do nieszczęścia. $Z$ kolei $W$ przedziale to pierwsze opowiadanie w cyklu, w którym mamy niejako in extenso przeniesienie się wydarzeń do tytułowego przedziału, czyli do realnego wnętrza pociągu ${ }^{4}$.

Koleje, parowozy i pociągi bardzo szybko zadomowiły się na kartach literatury i w sztukach plastycznych. Od początku istnienia kolei podróżowanie pociągiem ujmowano w literaturze dialektycznie. W XIX wieku podróż koleją żelazną była bowiem, z jednej strony, dowodem rozwoju przemysłowego, entuzjastycznym symbolem industrializacji, zmian socjalnych, demokracji, energii, wolności i wielu potencjalnych, zdolnych odmienić życie możliwości. Z drugiej jednak strony podróż pociągiem kojarzyła się z destrukcją, niebezpieczeństwem, destabilizacją, ingerencją w naturę, terrorem coraz to liczniejszych katastrof. Podróżowanie koleją wydawało się swego rodzaju patologią: zatłoczone hale dworcowe, klaustrofobiczne przestrzenie powodowały gwalt na ludzkiej psychice, wyrwanej ze swego naturalnego, pastoralnego kontekstu ${ }^{5}$. Pierwiastkowi optymistycznemu, połączonemu z ruchem, czyli z możliwością szybkiego pokonania przestrzeni, od początku towarzyszył czynnik anarchiczny, egoistyczny, nieuporządkowany, związany z zaburzeniami praw natury. Społeczne wyobrażenia i lęki dotyczące kolei szły w parze z realnym, traumatycznym doświadczeniem podróży ${ }^{6}$. Przemieszczanie się pociągiem szybko stało się metaforą ludzkiego losu; było kruche, nieprzewidywalne i mogło urwać się w dowolnym momencie. Pociąg, podstawowy znak tego typu doświadczeń w literaturze, miał więc charakter głęboko binarny, spolaryzowany, był odzwierciedleniem dialektyki zmechanizowanego, wywołanego przez czynnik industrialny ruchu i ludzkich, ujawniających się w czasie jazdy, głęboko skrywanych emocji.

Tematem podstawowym opowiadania Grabińskiego jest ukazanie niszczącej siły brutalnego erotyzmu oraz zbrodni będącej konsekwencją walki o kobietę, rozgrywającej się $\mathrm{w}$ tytułowej przestrzeni pędzącego pociągu. $W$ przedziale to tekst niemalże naturalistyczny, opisujący z detalami działanie ukrytych w psychice człowieka instynktów i pożądań. Fabuła przedstawia kilka godzin podróży Godziemby, głównego bohatera, nazywanego w utworze „fanatykiem ruchu”". Protagonista nie zastanawia się nad tym, do jakiego pociągu wsiada i po co jedzie, liczy się dla niego wyłącznie „bycie w ruchu”, czyli podróżowanie i pokonywa-

${ }^{4}$ Zob. M. Kochanowski, op. cit., s. 304.

${ }^{5}$ Zob. L. Marx, The Machine in the Garden. Technology and the Pastoral Ideal in America, New York 1964, rozdz. Two Kingdoms of Force.

${ }^{6}$ Zob. N. Daly, Literature, Technology and Modernity 1860-2000, Cambridge 2004.

${ }^{7}$ W dwóch innych opowiadaniach zbioru, w Smoluchu i w tytułowym Demonie ruchu, pojawia się ta sama postać, właściciel ziemski Szygoń, który uzależniony jest od morderczego pędu i jazdy pociągiem. Pęd ten wyznacza jego egzystencję. 
nie przestrzeni wywołujące stan ciągłego podniecenia, połączonego z zuchwałą pewnością siebie. Jazda pociągiem całkowicie przemienia Godziembę. W zwyczajnym życiu bohater ten uchodzi za nieśmiałego i niezdolnego do kontaktów towarzyskich z ludźmi, dopiero $\mathrm{w}$ przedziale staje się duszą towarzystwa, dowcipnisiem raczącym pozostałych pasażerów licznymi anegdotami. Sam narrator nazywa go „niedołęgą życiowym”, przemieniającym się „w skorego do zaczepki awanturnika, który mógł być nawet niebezpiecznym” (WP 23). Istnieją również liczne konsekwencje takiego awanturniczego trybu życia bohatera, który „każdą niemal podróż odchorowywał: po chwilowej zwyżce sił psychofizycznych następowała tym gwałtowniejsza reakcja” (WP 23).

W czasie jednej z podróży Godziemby do jego przedziału dosiada się młode małżeństwo. W ich wyglądzie dominują akcenty witalistyczne, on ma „silnie zarysowane brwi”, ona zaś „bujne, gęste włosy”, „twarzyczkę drobną; świeżą i dorodną” (WP 24). Wracają z gór, mają opalone twarze, emanują „młodością i zdrowiem”, są „mocno opyleni kurzem” (WP 24). Narrator dokładnie opisuje doświadczenia urlopowe Rastawieckich; spędzili w górach osiem dni, częściowo podróżowali na rowerze, kilka razy zaskoczył ich deszcz i brzydka pogoda. Mężczyzna jest lubiącym swą pracę inżynierem, z powodu nawału zajęć musi wracać z urlopu. Godziemba rozpoczyna namiętny i przelotny flirt z kobietą, która w czasie snu męża oddaje się cielesnemu podnieceniu i przyjemności erotycznej. Po obudzeniu Rastawiecki wdaje się w krótką walkę z Godziembą, zakończoną tragiczną śmiercią tego pierwszego pod kołami pociągu. Oszołomiona starciem dwóch mężczyzn i śmiercią męża Nuna całkowicie poddaje się demonicznemu bohaterowi, postanawiając zostać z nim na zawsze. Jednak w protagoniście po opuszczeniu pociągu budzi się lęk z powodu konsekwencji popełnionego czynu, poza pociągiem bohater traci swoją wewnętrzną moc i ucieka od spotkanej kobiety.

Motyw przemiany bohatera, wyzwolenia jego wewnętrznych, ukrytych sił przez czynniki zewnętrzne jest tematem pojawiającym się $\mathrm{w}$ wielu wczesnomodernistycznych utworach. Nie sposób nie zauważyć podobieństwa treści omawianego opowiadania ze znaną nowelą Dziwna historia doktora Jekylla i pana Hyde’a Stevensona, chociaż inspiracji z pewnością można by jeszcze przywołać wiele ${ }^{8}$. Doktora Jekylla ożywiała i pobudzała przemiana w Hyde’a, bohater Stevensona był znudzony swoją egzystencją i edukacją, a także otaczającą go kulturą wiktoriańską, szukał nowych wrażeń, które dostarczyła mu wynaleziona przez siebie mikstura, przemieniająca go w pozbawione zahamowań moralnych monstrum. Jekyll zamieniony w Hyde’a stawiał się niejako poza dobrem i złem, u Grabińskiego cudowną miksturę zastępuje jazda pociągiem. To ona przemienia Godziembę, czyniąc go nie tyle odważniejszym i silniejszym niż jest w rzeczywistości, ile zmieniając w jednostkę całkowicie pozbawioną skrupułów. Grabiński znał również autorów, którzy interesowali się tematyką związaną z sobowtórami, rozszczepieniem osobowości, instynktami i podświadomością, czytał Hoffmanna, Wilde’a, Strindberga czy Meyrinka. Wydaje się, iż jakąś inspiracją dla pisarza mogła być także wczesna twórczość Stanisława Przybyszewskiego, który chociażby w Requiem aeternam pisał o represyjnym działaniu różnego rodzaju systemów normatywnych, regulujących życie jednostek, takich jak wiara, nauka, kultura.

8 Jak zauważa Wojciech Tomasik (Ikona nowoczesności. Kolej w literaturze polskiej, Wrocław 2007, s. 117): „Można chyba już pokusić się o wskazanie istotnego rysu polskich opowiadań kolejowych. Otóż chodzi o formę, dla której ważnym układem odniesienia okazuje się modernistyczny dyskurs o kulturze [...]. Opowiadania kolejowe mówią o problemach czasów, których same są wytworem". 


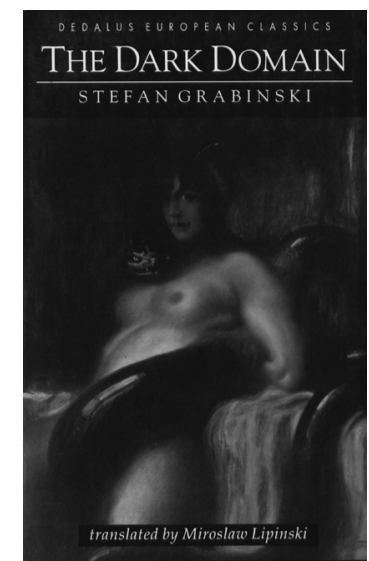

S. Grabiński, The Dark Domain, Deadalus, Sawtry; Hippocrene Books, New York

1993
W duchu epoki jest również sylwetka femme fatale, czyli Nuna, stająca się przyczyną starcia mężczyzn, która po zwycięstwie Godziemby, niczym bluszcz, obejmuje go parą „,iepłych, giętkich jak wężowe sploty" (WP 28) ramion. Kobieta w opowiadaniu Grabińskiego jest pierwiastkiem destruktywnym, widać tu wyraźny wpływ czytanego przez pisarza Weiningera. Nunę fascynuje człowiek silny, w ramionach Godziemby nie czuje żalu ani tęsknoty za zamordowanym mężem. Jako pierwsza zaczyna prowokować bohatera: „Lecz oczy jej fosforyzowały w półmroku drapieżnie, dziko, wyzywająco" (WP 27). Bohaterka uosabia ślepy popęd, działający niejako w opozycji do pewnych norm kulturowych oraz sankcji społecznych, jakim jest chociażby jej małżeństwo.

\section{Demon w maszynie}

Szeroko rozumiana nowoczesność wytworzyła liczne fenomeny związane z rozwojem przemysłowym, takie jak: kino, reklama, oświetlenie gazowe, które stały się również częścią obrazowania literackiego w pierwszych latach XX wieku. Do modernistycznych obrazów zaliczyć należy również kolejowe dworce i wypełnione podróżnymi hale, pociąg, lokomotywę czy też przedziały. Pociąg pojawiał się bardzo często na kartach literatury XIX wie$\mathrm{ku}$, a w rodzimym piśmiennictwie mniej więcej od lat 40 . tego stulecia ${ }^{9}$. Powstawały nawet dramaty, które w latach 60. i 70. XIX wieku były z powodzeniem wystawiane na scenach londyńskich teatrów, gdzie wjeżdżające na scenę lokomotywy próbowały przejechać niewinnych ludzi ${ }^{10}$. Podróżowanie pociągiem mogło być atrakcyjne dla pisarzy, gdyż sprzyjało ukazaniu anonimowości i podatności na przypadkowe, jednorazowe spotkania, uwalniało człowieka od zobowiązań wobec własnej przeszłości, nadawało jego wypowiedziom i czynom atmosferę chwilowego „tu i teraz”. Pokusa wolności, konsekwencje kreacji zostają bowiem w przedziale, wśród pasażerów, z którymi prawdopodobnie już nigdy nie przyjdzie się postaciom spotkać. Przedział bowiem to sfera zawieszona dokładnie w przestrzeni pomiędzy tym, co prywatne, a tym, co publiczne. Przedział pociągu funkcjonował również jako miejsce zbrodni, stając się w ten sposób sceną przestępstwa ${ }^{11}$. Pociąg czyniący ze zwyczajnych podróżnych odmieńców, psychopatów i zabójców jest obecny chociażby w Sonacie Kreutzerowskiej Tołstoja, Bestii ludzkiej Zoli, powieści Patrycji Highsmith Znajomi z pociagu z 1950 roku. Z kolei przedział będący tłem dla miłosnych igraszek bohaterów pojawia się chociażby w naszej Lalce ${ }^{12}$. Badacz „literatury kolejowej”, Matthew Beaumont, nazywa pociągowy przedział przestrzenią typowo modernistyczną, ponieważ jego istnienie jest warunkowane anonimowością, przypadkowością i dziwnymi spotkaniami ${ }^{13}$. Przestrzeń ta to bowiem miejsce, w którym nie tylko spotkamy kogoś dziwnego, ale i my sami możemy się okazać dla innych dziwni i niebezpieczni ${ }^{14}$.

\footnotetext{
9 W. Tomasik, op. cit., s. 17.

10 N. Daly, op. cit., s. 10-12.

11 Zob. M. Beaumont, Railway Mania: The Train Compartment as the Scene of Crime, [w:] The Railway and Modernity: Time, Space and the Machine Ensemble, ed. M. Beaumont, M. Freeman, Bern 2007.

12 Zob. analizę tej sceny w: J. Sosnowski, Czas żelaznych potworów, [w:] Szybko i szybciej. Eseje o pośpiechu w kulturze, red. D. Siwicka, M. Bińczyk, A. Nawarecki, Warszawa 1996, s. 134-135.

13 M. Beaumont, op. cit., s. 130-132.

14 Ibidem, s. 130.
} 
Jazda pociągiem wprowadzała do literatury stan nieograniczonych możliwości, czyniąc $\mathrm{z}$ bohatera osobę całkowicie wolną od swojej przeciętności, umożliwiając mu jednocześnie dowolność w zakresie różnych kreacji. Ale podróżujący koleją nie jest baudelairowskim flâneurem - podmiot Kwiatów zła był aktorem przelotnym, istniejącym w krótkiej chwili, wyznaczonej długością przypadkowego spotkania. Dla Grabińskiego kolej ma znaczenie przenośne, jest „symbolem życia i jego ogniście pulsujących tętn - symbolem demonizmu ruchu, przepotężnej siły, znikąd rodem, co pędzi światy przez międzyplanetarne przestworza w kręgach wirów bez początku i końca"15. Kolej przekracza zdolności ludzkiego poznania, jest praprzyczyną wpływającą na indywidualne wybory i uczynki. Bohater działający $\mathrm{w}$ przestrzeni pociągu, $\mathrm{w}$ przedziale, ma co najmniej kilka godzin na zaaranżowanie indywidualnego spektaklu, na stworzenie siebie samego. Transport zmienia sposób zachowania człowieka. Kreacja zaczyna się najczęściej od przypadkowych sygnałów, od obserwacji i spojrzenia. Rytm i ruch pociągu nadaje spektaklowi swoiste doświadczenie. Pożądanie targające Godziembą oraz zbrodnia, której się dopuszcza, są modyfikowane przez jazdę pociągiem. Kluczem do zrozumienia zarówno całości cyklu Grabińskiego, jak i omawianego opowiadania jest rola ruchu wyznaczona przez pociąg, który uświadamia jednostce zwierzęcą prawdę o jej naturze, doprowadza do tego, iż zakochana w swoim mężu inżynierowa zdradza go ze świeżo poznanym podróżnym. Odmiennośćjazdy pociągiem od innych chwil w życiu Godziemby jest widoczna w jego działaniu, podróżowanie wyzwala w nim niepowstrzymane doznanie erotyczne: „uczuł ku niej nieprzeparty pociąg” (WP 25), i jeszcze: „Tkwiło coś w istocie pędzącego pociągu, coś, co galwanizowało słabe nerwy Godziemby podniecało silnie choć sztucznie nikłą energię życiową" (WP 22). Maszyna, przyśpieszając, „elektryzuje wolę” bohatera, wytwarza u niego „nerwicę kolejową”.

Działanie postaci motywowane jest przez ruch pociągu, który w tekście nabiera cech niezależnych od człowieka, stając się niejako reżyserem zachowań głównych bohaterów. Wrażenie niemożności zapanowania nad własnym losem, fatalizm działania postaci jest przez narratora w opowiadaniu podkreślone kilkukrotnie: „Fatalny czar rozpostarł nad tym trojgiem ludzi swe władztwo i pędził na manowce szału i zapamiętania” (WP 26). Pęd maszyny wpływa na somatyczne zachowanie Godziemby, stymuluje jego oddech. To pociąg, jak zauważa narrator, przyczynia się do intensyfikacji doznań bohatera, „usamodzielnia” wrażliwca: „pociąg w ruchu działał nań jak morfina, zastrzyknięta w żyły nałogowca” (WP 23), narrator dostrzega, że bohater „opiumizuje się ruchem pociągu” (WP 23). Pokonujący przestrzeń pociąg rządzi zbliżeniami, dotyk fizyczny Godziemby i inżynierowej sprawia wrażenie zewnętrznie wykreowanego, odbywa się wtedy, gdy „wagon przechyla się na skręcie”, powodując dotknięcie ich kolan. Zachowanie pojazdu, który jest nieoswojony, irracjonalny, znajduje odzwierciedlenie w zachowaniu Godziemby, ale też omamia Rastawieckiego, sprawia, iż nie widzi on wybitnie erotycznej relacji jego żony i przypadkowo spotkanego, obcego pasażera. Narastające erotyczne pobudzenie postaci jest ściśle związane z ruchem maszyny, po pierwszych dotknięciach bohaterów otrzymujemy opis jazdy pociągu, który zawiera obrazowanie w sposób symboliczny odsyłające do opisów charakterystycznych dla aktu seksualnego: „A pociąg mknął dalej bez tchu, wbiegał na wzgórza, ześlizgiwał się w doliny, pruł przestrzeń piersią maszyny. Grzechotały szyny, dudniły koła, kłańcały zworniki” (WP 26).

${ }^{15}$ S. Grabiński, Z mojej pracowni. Opowieść o "Maszyniście Grocie”. Dzieje noweli - przyczynek do psychologii tworzenia, "Skamander" 1920, z. 2. Za:TLSG, s. 149. 
Pociąg ułatwia kochankom romans, gdyż usypia Rastawieckiego: „Wtem na tle stukotania wozu zaczęły wydobywać się z ust inżyniera ostre, chrapiące tony” (WP 27). Narrator pisze o „jakiejś szczególnej ślepocie zarzucającej przed nim coraz głębszą zasłonę" (WP 25). Stosunek erotyczny Godziemby i Nuny zostaje przerwany atakiem inżyniera, który jest człowiekiem fizycznie większym i silniejszym od Godziemby, ale ten wydaje się władać jakąś nadludzką siłą: „W tym człowieku na pozór nikłym i słabym obudziła się jakaś nerwowa, występna moc; jakaś zła, demoniczna siła podnosiła jego wątłe ramię, wymierzała ciosy, paraliżowała atak" (WP 28). Nadprzyrodzona moc, jaką dysponuje bohater, jest rezultatem wpływu maszyny obdarowującej go tytanicznymi możliwościami. Pociąg nadaje ich walce rytm, śmiertelna potyczka opisywana jest w sposób charakterystyczny dla pracy parowozu: „Zmagali się w ciszy nocnej, przerywanej hukiem pociągu, łoskotem nóg lub przyspieszonym oddechem ciężko pracujących piersi...' (WP 28). Ruch o charakterze symbolicznym, ponadczasowym jest ruchem bergsonowskiego élan vital ${ }^{16}$, nieokiełznaną energią (por. TLSG, s. 118), która zbiera się w postaci bohatera: „Skupioną przedziwnie energią dźwigał jej łamiącą mu się w ramionach postać, gotów do zapasów z całym światem" (WP 29). Ostatecznie to Godziemba wygrywa, wypychając Rastawieckiego pod koła pociągu, a pociąg opiekuńczo chroni mordercę, tłumiąc krzyk ofiary.

Po zabójstwie bohater jest jeszcze pod wpływem działania maszyny: „Mówi tonem spokojnym, pewnym swych męskich celów, obojętnym na sąd ludzki” (WP 29). Ale już bezpośrednio po opuszczeniu pociągu, w czasie socjalizacji i spotkań z innymi anonimowymi ludźmi, zachowanie bohatera się zmienia. „Tłum” wchłania Godziembę i Nunę, narzuca z powrotem ich wyparte przez jazdę role. Bohater staje się więc ponownie jednostką anonimową, słabą, „jednym z wielu”. Świadomość opieki nad drugim człowiekiem, a więc zachowanie społeczne, staje się mu ciężarem. Pozbawiony warstwy ochronnej pociągu na powrót zaczyna funkcjonować w świecie, który czyni z niego osobę zakompleksioną i przeciętną: „W mgnieniu oka wyczołgała się skądś z załomów duszy groza, obłąkana groza i zjeżyła mu włosy... Wyszczerzył ostre kły ohydny, podły strach...” (WP 29). Bycie wśród innych nadaje sytuacji prawdziwe, normatywne znaczenie, które przez samego bohatera zostało wcześniej wyparte: „Został tylko morderca i nędzny tchórz” (WP 29). W uwolnieniu, ucieczce od Nuny pomaga mu tłum, dający poczucie anonimowości. Wyjście przez „ciemny korytarz” i szalona ucieczka pomiędzy „zaułkami nieznanego miasta” ujawnia prawdę dotyczącą nabierania świadomości popełnienia morderczego uczynku.

\section{Tętno psychiczne}

Artur Hutnikiewicz podkreślił wpływ koncepcji Freuda na twórczość Grabińskiego ${ }^{17}$, a szczególnie na widoczny w pismach autora Wstępu do psychoanalizy konflikt pomiędzy

${ }^{16}$ "Lecz jeżeli moje ciało jest przedmiotem zdolnym pobudzać działanie rzeczywiste i nowe w przedmiotach, które je otaczają, musi zajmować względem nich uprzywilejowane stanowisko". H. Bergson, Materia i pamięć. Studium nad stosunkiem ciała do ducha, tłum. K. Bobrowska, Warszawa 1930, s. 20.

17 TLSG, s. 244. Z kolei Laura Marcus zwraca uwagę na kulturowe znaczenie traumy i szoku w narracjach kolejowych na przełomie XIX i XX wieku. Już Freud, według badaczki, kładł nacisk na mechaniczną agitację ciała, która odbywa się w pociągu. Więcej w: L. Marcus, Psychoanalytic Training: Freud and The Railway, [w:] The Railway and Modernity, s. 155. 
libido a cenzurą, interesujący pisarza. Słuszne to spostrzeżenie, ponieważ już w samym opowiadaniu $W$ przedziale występują liczne określenia, które można odnieść do sfery nerwowości: „nerwy Godziemby”, „tętno psychiczne”, „wola”. Narrator informuje nas o specyficznym działaniu pociągu na Godziembę: „pociąg w ruchu działał nań jak morfina, zastrzyknięta w żyły nałogowca" (WP 23). Główny bohater opowiadania uchodzi za naturę chłodną, a „pod względem płciowym wstrzemięźliwą” (WP 25), odżywa dopiero w pociągu, który wyzwala w nim ukryte głęboko popędy. Jedną z nich jest wspominany przez narratora "demon płci”, czyli doświadczenie wolności ujawniające się pod wpływem zniwelowania krępujących mechanizmów represyjnej kultury.

Zygmunt Freud w artykule Niesamowite ${ }^{18}$ zwraca uwagę na tytułową sferę, w której kryje się stan będący „rodzajem tego, co budzi trwogę, co zaś sprowadza się do tego, co od dawna znane, znajome” ${ }^{\prime 1}$. „Niesamowite”, jako przeciwieństwo „samowitego”, czyli oczywistości, ujawnia się wtedy, gdy pojawia się „niepewność intelektualna”, sytuacja „braku rozeznania”. Freud bada pochodzenie słowa „niesamowite” przez filologiczne zestawienie go $\mathrm{z}$ „samowitym”. Samowite to: kameralne, bezpieczne, przyjazne, wygodne. „Niesamowite” to nieznane, niewygodne, dziwne, ujawnia się szczególnie w różnych chwilach „niezamierzonego powtórzenia”, zdublowania bądź zwielokrotnienia wydarzeń i trafów, na które nie mamy wpływu. Szczególnie zaś „to co budzi lęk, staje się niesamowitym”20.

„Niesamowite” skupia w sobie wszystko to, czego nie akceptuje „ego”. To powrót do pierwotnego stanu, do naszej naturalności. „Niesamowite” oznacza uaktywnienie się czynników tłumionych przez społeczeństwo, ujawnia się w odczuciu działania niezidentyfikowanej siły, która pierwotnie wydaje się nam znajoma. Symbolem działania takiej siły może być pociąg, znaczące jest już określenie „demon ruchu”. Jazda pociągiem działa na bohatera pobudzająco, zwiększa jego poziom adrenaliny i efektywności, pobudza działanie mięśni. Wolfgang Schivelbusch zauważyl, że pasażer w pociągu niejako wchłania swoim ciałem te wstrząsy, których nie jest w stanie zaabsorbować maszyna ${ }^{21}$. Mięśnie są pobudzane krótkimi wibracjami, a ciało zmęczone ciągłym stresem. W uznanych XIX-wiecznych pismach medycznych, takich jak „Lancet”, pojawiały się liczne artykuły przestrzegające przed jazdą pociągiem jako wywolującą choroby mózgu prowadzące do paraliżu ${ }^{22}$. Pierwsze informacje o przemianie Godziemby pod wpływem jazdy otrzymujemy w momencie przechodzenia dnia w mrok, po krótkiej charakterystyce bohatera następuje wzmianka: „Na dworze ściemniało się tymczasem zupełnie” (WP 23). Hipnotyczne, pulsacyjne kołysanie się pociągu doprowadza do jednoczesnego uwolnienia „innego” Godziemby, pewnego siebie, amoralnego potwora będącego pod wplywem działania „niesamowitego”. Doświadczenie tego stanu prowadzi do zatracenia zdolności rozróżniania granic pomiędzy fantazją a rzeczywistością. Godziemba przemienia się w pociągu z nieśmiałego marzyciela $\mathrm{w}$ „pełnego woli i poczucia własnej wartości życiowca” (WP 22), pociąg go odmienia, dając mu niespożyte siły i moce.

18 Z. Freud, Niesamowite, [w:] idem, Prace psychologiczne. Dzieła, t. 3, tłum. R. Reszke, Warszawa 1996. W powyższym tekście słowo "niesamowite”, dla zachowania klarowności wywodu, oznaczam kursywą. Zob. też The Railway and Modernity, s. 130-131.

19 Z. Freud, op. cit., s. 236.

20 Ibidem, s. 254.

${ }^{21}$ W. Schivelbusch, The Pathology of the Railroad Journey, [w:] idem, The Railway Journey: The Industrialization of Time and Space in 19th Century, Berkeley 1987, s. 117.

22 R. Harrington, The Railway Journey and the Neuroses of Modernity, [w:] Pathologies of Travel, ed. R. Wrigley, G. Revill, Atlanta 2000, s. 249. 


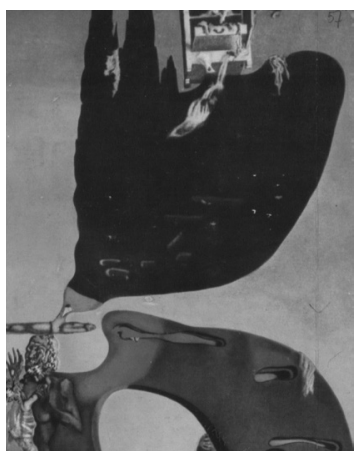

S. Grabiński, Antologia nuvelei fantastice,

Ed. Univers, Bucureşti 1970

Tytułowy przedział staje się w opowiadaniu przestrzenią spotkania płci, niweluje tradycyjne różnice i przestrzenie zarezerwowane wyłącznie dla mężczyzn lub kobiet. Przedział w czasie jazdy porusza się rytmicznie, a wspomniana rytmiczność i posuwistość ruchów maszyny ewokuje jednoznaczne, seksualne skojarzenia. Fabuła opowiadania od początku wciąga czytelnika niejako do środka tekstu, do tytułowego przedziału. Puste pola za oknem, które otacza mrok, symbolizują moment przejścia, „wyczyszczenia” świadomości. Znamienne jest szczególnie pierwsze zdanie krótkiego opowiadania: „Pociąg czhał przestrzenią szybki jak myśl” (WP 22). Myśl jest w tym wypadku synonimiczna do pojęcia logosu. Rozum zostaje w tekście zawieszony, w pociągu uruchamia się ciąg doświadczeń związanych z tym, co pozarozumowe, instynktowne, „niesamowite”. Podkreśleniem tego stanu jest pora dnia, a także mijane przestrzenie: „puste jak okiem sięgnąć ugory” i - co wydaje się określeniem kluczowym dla analizowanego tekstu - telegraficzne druty, które „to szły w górę, to spadały w dół" (WP 22). Pulsacyjny widok znikających i pojawiających się drutów za oknem jest symboliczną zapowiedzią stosunku erotycznego bohaterów. Emocje, pożądanie i ruch maszyny stają się jednością, także w warstwie leksykalnej, chociaż cytat ten już został przytoczony w niniejszym tekście, to przypomnijmy go jeszcze raz: „uczuł ku niej nieprzeparty pociąg” (WP 25). Widoczne za oknem przewody elektryczne nabierają charakteru hipnotycznego, wraz z głównym bohaterem zostajemy wciągnięci w świat, który ma swój oddzielny, niezależny rytm.

Uaktywnienie planu psychologicznego odbywa się już na poziomie znaczących imion własnych w tekście. Nuna to postać niedojrzała emocjonalnie, łatwo wdająca się w incydentalny stosunek erotyczny. O jej instynktownym, libidalnym charakterze świadczy nie tylko błyskawiczny romans z przypadkowym podróżnym, ale i imię bohaterki. Określenie „Nuna” konotuje bowiem dźwięk charakterystyczny dla dziecięcego gaworzenia, pokrewne jest również określeniu „Luna” - księżyc, będący symbolem tego, co tajemnicze i nieuświadomione, mrocznej natury człowieka. Z kolei w nazwisku Godziemby kryje się bóg (God), oznaczający niezależność. Opisywane małżeństwo Rastawieckich symbolizuje potęgę urody i młodości, sam inżynier jest człowiekiem, którego charakteryzuje szczerość i przenikliwość; przebudzony nazywa adwersarza faunem. To wyraźna aluzja do dionizyjskiego charakteru działania maszyny, do szału i upojenia. Jazda pociągiem stanowiła bowiem swoiste przeciwieństwo samo w sobie, była uosobieniem dialektyki tego, co dionizyjskie, z tym, co apollińskie ${ }^{23}$. Nawiązanie do mitologii pojawi się w opowiadaniu jeszcze jeden raz: Godziemba po zabiciu Rastawieckiego pragnie z Nuną uciec do nieokreślonego kraju śródziemnomorskiego, w którym „biały las bożyszcz wieńczy skronie wawrzynowym wieńcem" (WP 29). W przytoczonym zdaniu mamy do czynienia ze swoistą syntezą, wieniec był częścią ikonicznych wizerunków Dionizosa, ale sam wawrzyn jest z kolei symbolem Apollona ${ }^{24}$. Bohater w pociągu staje się więc bogiem narzucającym swój świat innym pasażerom, narzuca zachowanie pozbawione jakichkolwiek zasad. W miarę rozwoju fabuły w postępowaniu Godziemby możemy zaobserwować zmianę wywołaną jazdą pociągiem, w jego oczach „pełgał żar i upojenie”, bohater emanuje „urokiem żądzy”, nawet jego tętno ulega w pociągu znacznemu przyśpieszeniu: „Serce biło wzmożonym tętnem, niby chcąc przyśpieszyć tempo jazdy...” (WP 22). Stosunek erotyczny Godziemby i Nuny nacechowany jest animalistycznym, wykluczającym jakiekolwiek zahamowania

\footnotetext{
23 Zob. R. Harrington, op. cit., s. 229.

24 Zob. H. Karczewska, Funkcja wieńców w tradycji antycznej, "Seminare” 2009, nr 26.
} 


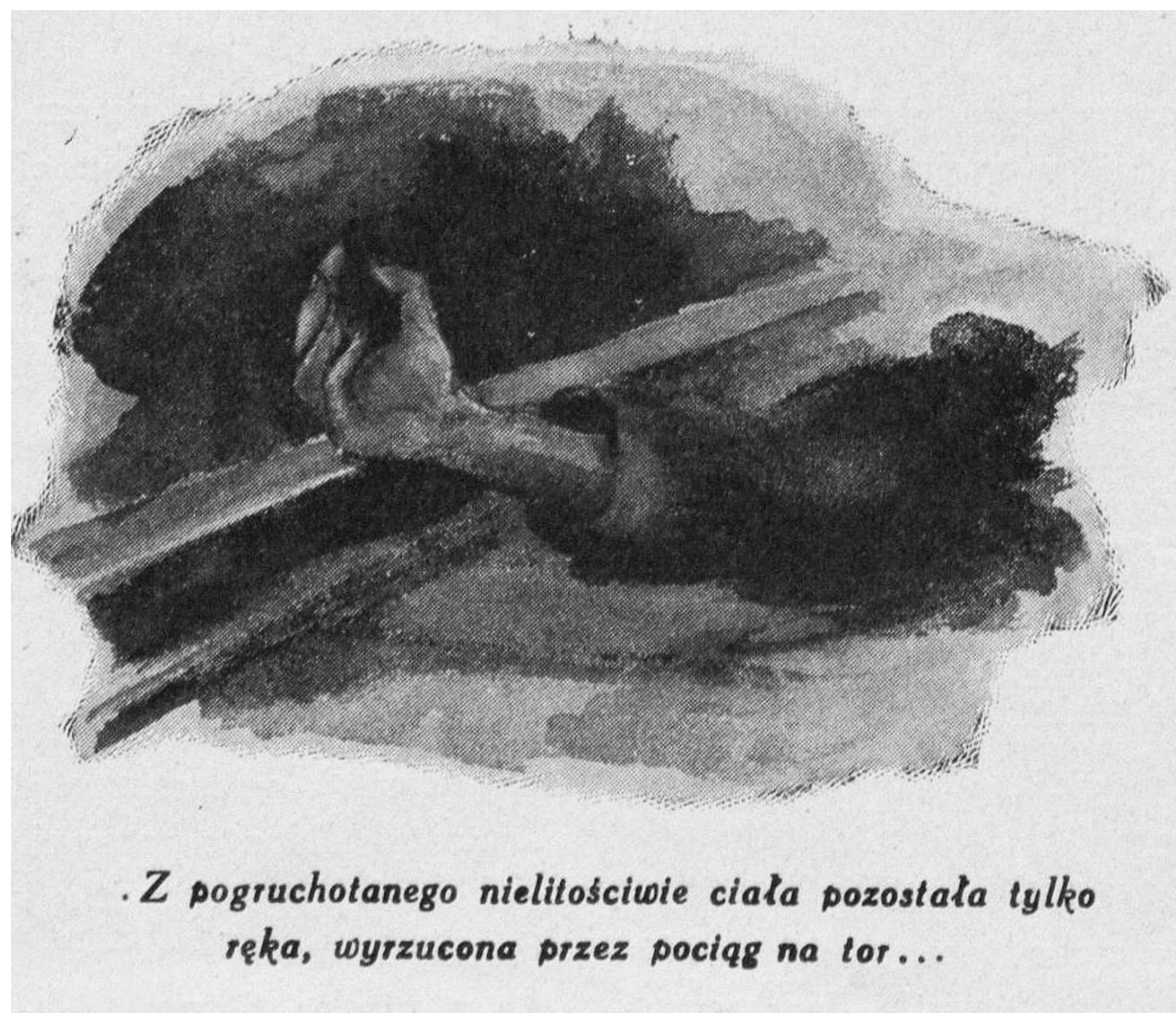

pożądaniem: „Godziemba brał ją. Brał jak płomień w skwarze pożaru, co niszczy i trawi, i spala, brał jak wicher w rozpasaniu szałów, swobodny, wolny stepów brat. Drzemiące żądze wybuchły czerwonym krzykiem i potargały wędzidła” (WP 27). Podkreślone w przywołanym opisie odwołania do żywiołów sygnalizują dzikość i brak opanowania obojga bohaterów.

Przeciwnikiem Godziemby staje się inżynier, przedstawiciel rozumu, reprezentant nauk ścisłych. Kobieta, Nuna, wydaje się tu postacią bierną, uzależnioną od silniejszego mężczyzny. Brak wyrzutów sumienia, jakichkolwiek emocji w postępowaniu bohatera, świadczy o zawieszeniu myślenia normatywnego, usunięciu go z doraźnego działania. Już po dokonaniu zbrodni zachowanie Godziemby naznaczone jest nieludzkim wręcz opanowaniem: „Przeciąg pędzącego parowozu rozwiewał mu włosy i studził gorączkę krwi. Wyjął cygarnicę i zapalił papierosa. Czuł się jakoś rześko, wesoło" (WP 28). Bohater w przedziale sytuuje siebie poza dobrem i złem, jego działanie wydaje się motywowane przez pęd pociągu, siłę biorącą w nawias zbiorową moralność. Bezgraniczna, czysta wolność uaktywnia euforyczny stan Godziemby, który doprowadza do tego, że staje się on nowym, „pewnym swym męskich celów" (WP 29) człowiekiem. llustracja do noweli Engramy Szatery, „Naokoło Świata" 1926, nr 28, rys. J. Kożuchowski 


\section{Podsumowanie}

Stefan Grabiński w opowiadaniu $W$ przedziale prezentuje fabułę w sposób dosyć szczególny, narrator sytuuje się bowiem w pozycji badacza obserwującego eksperyment, a nie oceniającego postępowanie głównego bohatera. Brak oceny działania Godziemby wydaje się w kontekście całego tekstu niezwykle znaczący; to nie o ludzki wymiar oceny zdrady czy zbrodni tutaj chodzi, ale o pokazanie pewnych sit $^{25}$, które modelują funkcjonowanie jednostki. W skrajnych wypadkach, według narratora, w działaniu człowieka ujawnia się bowiem niezidentyfikowana potęga, wobec której nasze zdolności myślenia normatywnego są niewystarczające do obiektywnej oceny sytuacji. Symbolem tej wiecznej mocy może być pociąg rozumiany jako „ikona nowoczesności”26.

Zastosowanie w powyższych rozważaniach freudowskiego pojęcia „niesamowitego” odzwierciedla animistyczną koncepcję wszechświata. „Niesamowite” ujawnia się w przedziale, punkcie węzłowym, jednoczącym dialektykę ruchu i pożądania, miejscu, gdzie to, co rzeczywiste, i to, co nieuświadomione, tworzą jedność. Ruch pociągu, w rozumieniu Grabińskiego, czyni z bohatera postać fragmentaryczną, rozbitą na cząstki wielu przypadkowych bodźców, doświadczeń i pożądań. Inicjacja w sferę tego, co ukryte, odbywa się w opowiadaniu poprzez pęd, demoniczne działanie maszyny, która na początku XX wieku była nie tylko symbolem postępu i techniki, ale i kojarzyła się z szaleństwem i śmiercią. Równie istotna w wypadku omawianego tekstu jest tytułowa przestrzeń, będąca metaforycznym sercem, rdzeniem pociągu, miejscem połączenia idealnej, mechanicznej maszyny i przypadkowych emocji pasażerów.

25 Artur Hutnikiewicz, pisząc o światopoglądzie pisarza, zauważa: „Niewzruszona wiara w istnienie jakiejś wyższej rzeczywistości duchowej, transcendentnej w stosunku do świata natury i niezależnej od niego, a będącej właściwym przeznaczeniem człowieka, głębokie przekonanie o prymacie pierwiastka duchowego jako podstawowej substancji bytu i jedynej siły istotnie stwórczej przed materią jako elementem pochodnym i niższym, przeświadczenie, że wszechświatem rządzi suwerenna, doskonała, wszystko wiedząca inteligencja, źródło głębokiej, choć często zagadkowej i niezrozumiałej logiki bytu, wreszcie niezachwiana ufność w wieczystość i nieśmiertelność istnienia, które jest ustawicznym ruchem, stawaniem się, dążeniem, twórczym podbojem nieznanego, zdobywaniem go za cenę śmierci o moralnego wysiłku w toku wielokrotnych kolejnych żywotów". TLSG, s. 156-157.

26 Korzystam z trafnego, dotyczącego kolei sformułowania Tomasika, które pojawia się w tytule cytowanej już książki. 


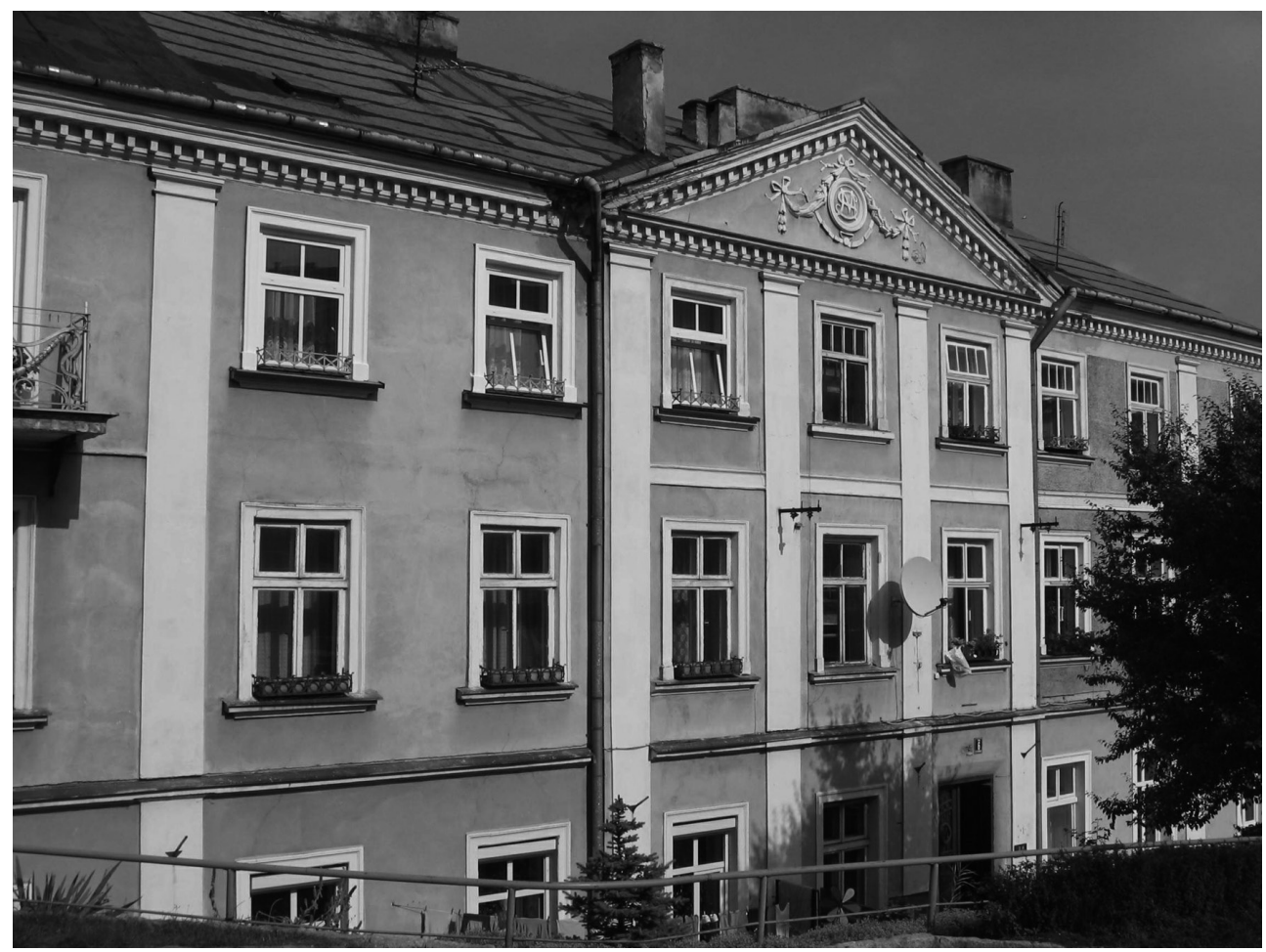

Kamienica, w której

Stefan Grabiński

mieszkał podczas

pobytu w Przemyślu

(1917-1921).

Fot. Tomasz Pudłocki, 2005 r.

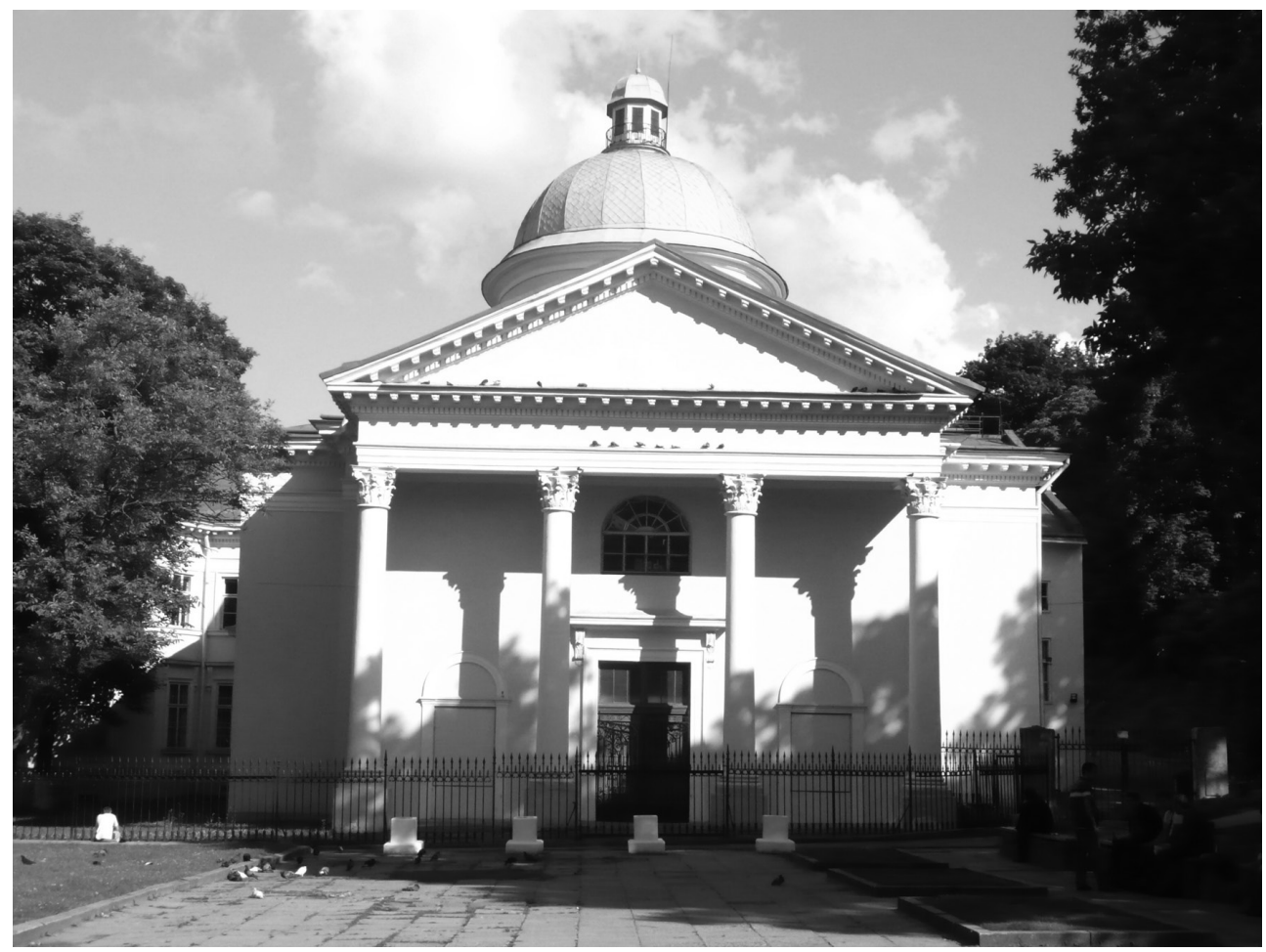

Budynek Ossolineum we Lwowie, obecnie siedziba Biblioteki im. Wasyla Stefanyka.

Fot. Tomasz Pudłocki, $2010 \mathrm{r}$. 


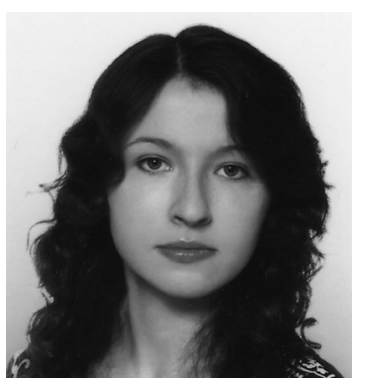

Katarzyna Trzeciak

Katarzyna Trzeciak - magister filologii polskiej i absolwentka podyplomowych Gender Studies na Uniwersytecie Jagiellońskim. Publikowała w internetowych pismach "Polisemia" oraz „E-splot". Interesuje się krytyką genderową oraz zagadnieniami transgresji w literaturze współczesnej. Opublikowała m.in. monografię Figury pożądania, figury pisania w wybranych nowelach Stefana Grabińskiego (2012). 